\title{
Compressibility Behaviour of Peat Stabilized with Fly Ash Using DMM: An Experimental and Numerical Study
}

\author{
M. Nithurshan'1, R. Nitharshan², M. C. M. Nasvi³ \\ 1B.Sc. Eng. (Hons)(Peradeniya), Lecturer, Department of Engineering Technology, University of Jaffna, Sri Lanka \\ ${ }^{2}$ B.Sc. Eng. (Hons)(Peradeniya), Department of Civil Engineering, University of Peradeniya, Sri Lanka \\ ${ }^{3}$ AMIE (Sri Lanka), B.Sc. Eng. (Hons) (Peradeniya), Ph.D. (Monash), Senior Lecturer of Civil Engineering, \\ ${ }^{3}$ Department of Civil Engineering, University of Peradeniya, Sri Lanka
}

\begin{abstract}
How to cite this paper: M. Nithurshan | R. Nitharshan | M. C. M. Nasvi "Compressibility Behaviour of Peat Stabilized with Fly Ash Using DMM: An Experimental and Numerical Study" Published in International Journal of Trend in Scientific Research and Development

(ijtsrd), ISSN: 2456-

6470, Volume-3 |

Issue-3 , April 2019, pp.432-438, URL: http://www.ijtsrd.co $\mathrm{m} /$ papers/ijtsrd 229 04.pdf

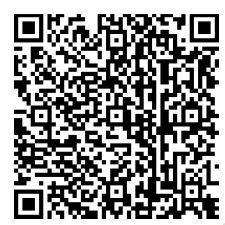

IITSRD22904
\end{abstract}

Copyright (C) 2019 by author(s) and International Journal of Trend in Scientific Research and Development Journal. This is an Open Access article distributed under the terms of the Creative Commons Attribution License (CC BY 4.0) (http://creativecommons.org/licenses/ by/4.0)

\section{ABSTRACT}

Peat is a type of soil made up of partially decomposed plant matters and contains high amount of pores. Therefore, it has high compressibility and low shear strength, which makes it as a geotechnically problematic soil. Two main methods of ground improvement include mechanical and chemical methods. In this research, chemical stabilization was used as ground improvement techniques and this method stabilizes the soil through the addition of chemical admixtures such as ordinary Portland cement (OPC), fly ash, lime etc. Major aim of this research was to study the compressibility characteristics of peat stabilized with ASTM class F fly ash (FA) using deep mixing method (DMM), and an experimental and numerical based study was adapted to achieve the aim. As part of the experimental study, testing including index properties test, direct shear test and consolidation test using Rowe cell apparatus were conducted, while PLAXIS 2D numerical package was used to simulate the laboratory Row Cell consolidation test to predict the consolidation characteristics of peat and FA stabilized peat. A FA dosage of $10 \%$ (by weight) was used to prepare the stabilized peat sample. Based on the experimental findings, peat used was classified as sapric amorphous peat. Addition of $10 \%$ FA increases the cohesion (c) and decreases angle of friction $(\Phi)$. Further compressibility parameters [coefficient of consolidation $(\mathrm{Cv})$, coefficient of secondary compression $(\mathrm{C} \alpha)$ and compression index (Cc)] decrease with the addition of $10 \% \mathrm{FA}$ and it is due to the chemical reaction between FA and water in the peat, producing a stiffer peatFA stabilized matrix. Percentage reduction in $\mathrm{Cv}$ and $\mathrm{C} \alpha$ are $12.7 \%-33.4 \%$ and $7.1 \%-25.93 \%$ depending on the normal stress, while the percentage reduction in $\mathrm{Cc}$ is $10.5 \%$. In addition, it was observed that PLAXIS can predict the consolidation behaviour of peat reasonably well.

Keywords: Chemical stabilization; Compressibility; Fly ash; Peat; Rowe cell; Stabilized column

\section{INTRODUCTION:}

Peat is a type of soil made up of partially disintegrated plant and organic matters under conditions of incomplete aeration and high - water content [12] and peat deposits are found where conditions are favourable for their formation. Its formation occurs when the rate of decomposition of organic materials is greater than the rate of decomposition. According to Bord and Mona [5], peatlands cover nearly 400 million hectares of the earth which is $3 \%$ of the total land surface area. In Sri Lanka, 2500 hectares of land is covered by peat land. Peat is classified mainly into two types: fibrous and amorphous peat. Based on visual observations, Von Post [14] further divided this into ten categories $\left(\mathrm{H}_{1}-\mathrm{H}_{10}\right)$ using Von Post scale system, where $\mathrm{H}_{1}$ is completely fibrous peat and $\mathrm{H}_{10}$ is completely amorphous peat. Peat differs in category from $\mathrm{H}_{1}$ to $\mathrm{H}_{10}$ due to degree of humification, water content, fiber content and botanical composition [9]. According to ASTM [2], standard classification of peat is narrowed down to three classes: (1) fibric (least decomposed with fiber content more than 67\%), (2) hemic (semi fibrous) and (3) sapric (most decomposed with fiber content less than 33\%).

Peat exhibits high compressibility, low bearing capacity, high natural water content, high water holding capacity and high rate of creep $[4,11]$ and poses serious problems in construction industry (localized bearing failures and slip failures) due to its long-term consolidation settlement even when it is subjected to moderate load $[10,11]$. Hence, peat is considered as unsuitable for supporting foundations in its natural state. In order to stabilize peat to overcome above problems, two ground improvement techniques are widely used. They are mechanical method and chemical method. There are many studies [7 - 11] focusing on the mechanical and chemical stabilization of peat. 
Duraisamy et al [7] suggested some mechanical methods for stabilizing peat. They were displacement and replacement, preloading with vertical drains and lightweight foundation system. In the mechanical method, there is no chemical reaction between soil and stabilizer.

Huat et al [8] stated that under chemical stabilization method, deep mixing method (DMM) is the widely used method for stabilizing organic soils like peat. This study presented the results of the compressibility parameters of fibrous, hemic and sapric with the help of peat stabilized with cement columns using DMM. Four composite peat samples (Peat: cement $=50: 50,30: 70,80: 20$ and 90:10) were prepared and tests were carried out using Rowe cell apparatus. It was concluded that the compressibility parameters decrease with an increase in cement content as the hardened soil - cement matrix was formed. In addition, effect of cement is higher on sapric peat due to high cation exchange capacity, surface area and $\mathrm{pH}$, and compressibility parameters can be improved by increasing the column area ratio. In addition, the results were simulated using finite element software, Plaxis 2D and it agreed well with the experimental findings. Therefore, it was extended to predict the ultimate bearing capacity of peat with full size cement stabilized columns ( $1 \mathrm{~m}$ in diameter and $5 \mathrm{~m}$ in height).

Huat et al [9] studiedthe effect of admixtures such as kaolinite, sodium silicate and calcium chloride along with cement on shear strength and moisture content of sapric peat. The results showed that by increasing kaolinite content and sodium silicate content (within 3\%), the shear strength was increased, and moisture content was decreased due to hydration and pozzolanic reactions. Calcium chloride increases the shear strength until net charge of the sample became zero and then shear strength decreases with the further addition of calcium chloride due to the deflocculating of larger particles.

Huat et al [10] conducted a research study on the effect of chemical admixtures [ordinary Portland cement (OPC) and lime] on the index and engineering properties (compaction and unconfined compressive strength) of tropical peat soils. It was noticed that maximum dry density and unconfined compressive strength were increased with an increase of $\mathrm{OPC}$ and lime contents while the optimum moisture content was decreased. Furthermore, performance of OPC was better than lime because the percentage of strength increment was high in OPC than in lime.

Kolay et al [11] studied the effect of class F pond ash (PA) on the stabilization behaviour of peat. Different proportions of PA (5\%, 10\%, 15\% and 20\%) were used with different curing periods and mainly unconfined compression strength (UCS) test was conducted. It was observed that UCS increased with the increase in percentage of PA and curing period.

The Lakwijaya power plant in Sri Lanka is the largest of its kind in Sri Lanka, and they produce about 200,000 metric tonnes of fly ash (FA) annually. Of the total produced amount, only about $30 \%$ is used for cement production, leaving huge amount of FA ending up in landfills. Utilizing this FA for construction application will be a sustainable solution as it will reduce the land pollution and will save time and energy associated with landfilling. Therefore, major aim of this research is to study the compressibility behaviour of peat stabilized with ASTM class F fly ash(FA) using experimental and numerical methods. A series of experiments including index property tests, direct shear test and consolidation test using Rowe cell apparatus test were conducted as part of the experimental study, while PLAXIS 2D numerical package was used to simulate the consolidation behaviour of raw and stabilized peat.

\section{Research Methodology}

This research comprises experimental and numerical study.

The detailed methodology for each is explained in the following sections.

\subsection{Experimental work \\ 2.1.1 Materials}

Undisturbed peat samples of $150 \mathrm{~mm}$ diameter and 1000 $\mathrm{mm}$ height were collected from Kalutara, Sri Lanka. The samples were collected using an Open Drive Thin Wall Tube sampler which is the simplest and most widely used among all the available samplers to collect undisturbed sample. The degree of disturbance was calculated using Area ratio $\left(\mathrm{A}_{\mathrm{r}}\right)$ and the value obtained was $10 \%$ and this is within the acceptable range. Soon after the sampler was withdrawn, the cylindrical tube was sealed with 'paraffin' wax to retain the natural moisture in it. FA used in this study was obtained from Lakwijaya power plant, Sri Lanka. The chemical composition of FA used is shown in Table 1.

Table 1 - The chemical composition of FA Constituents Percentage / $(\%)$

\begin{tabular}{|c|c|}
\hline $\mathrm{SiO}_{2}$ & 52.03 \\
\hline $\mathrm{Al}_{2} \mathrm{O}_{3}$ & 32.31 \\
\hline $\mathrm{Fe}_{2} \mathrm{O}_{3}$ & 7.04 \\
\hline $\mathrm{CaO}$ & 5.55 \\
\hline $\mathrm{MgO}$ & 1.30 \\
\hline $\mathrm{SO}_{3}$ & 0.07 \\
\hline $\mathrm{K}_{2} \mathrm{O}$ & 0.68 \\
\hline $\mathrm{Cl}$ & 1.00 \\
\hline
\end{tabular}

\subsubsection{Experimental Methodology}

\section{A. Index properties}

Von Post classification test was conducted to classify peat between $\mathrm{H}_{1}$ and $\mathrm{H}_{10}$ scale [14]. In this test, peat sample was squeezed through the fingers and the observations were made based on the colour of the water after squeezed out.

Atterberg limits were determined using BS 1377: part 2: 1990. Liquid limit test was done using cone penetrometer method and straight - line best fitting curve was plotted using moisture content and penetration values. Moisture content corresponding to $20 \mathrm{~mm}$ cone penetration was taken as liquid limit. Loss of ignition test was conducted to find organic content using BS 1377: part 2: 1990 method and it was calculated from the weight of the sample lost during heating at $440 \stackrel{\circ}{\circ}$ divided by the weight of the sample before heating. Specific gravity test was conducted using small pyknometer method following the guidelines given in BS 1377: part 2: 1990 .

\section{B. Direct shear test (BS 1377: part 7: 1990)}

Direct shear test was conducted to obtain shear strength parameters [cohesion $(c)$ and friction angle $(\Phi)$ ] of raw and FA stabilized peat. A square sample of length $60 \mathrm{~mm}$ and height $20 \mathrm{~mm}$ was placed into the mould and $0.2 \mathrm{~mm} / \mathrm{min}$ shearing speed was applied to each sample under the normal 
pressuers of 50, 100 and $200 \mathrm{kPa}$. This test was continued until either the shear failure takes place, or the shear displacement reaches $10 \mathrm{~mm}$.

\section{Consolidation test using Rowe cell apparatus (BS 1377: part 6: 1990)}

Compared to conventional odeometer apparatus, Rowe cell has many advantages and the key features of Rowe cell include: (1) hydraulic loading system in Rowe cell enables the sample to undergo with less susceptible for vibration effects; (2) back pressure can be applied to stimulate the in situ conditions; (3) it has drainage control facilities and (4) it has ability to measure the pore water pressure [5]. The consolidation tests on peat were performed to determine compressibility characteristics such as compression index $\left(\mathrm{C}_{\mathrm{c}}\right)$, coefficient of secondary compression $\left(\mathrm{C}_{\alpha}\right)$ and coefficient of consolidation $\left(C_{v}\right)$. Two types of samples were used for Rowe cell test: (1) raw peat sample with $150 \mathrm{~mm}$ diameter and $50 \mathrm{~mm}$ height [Figure 1(a)]; (2) peat with a central FA stabilized column [Figure 1(b)]. The FA stabilized column was prepared with peat: FA of $90: 10$ by weight.

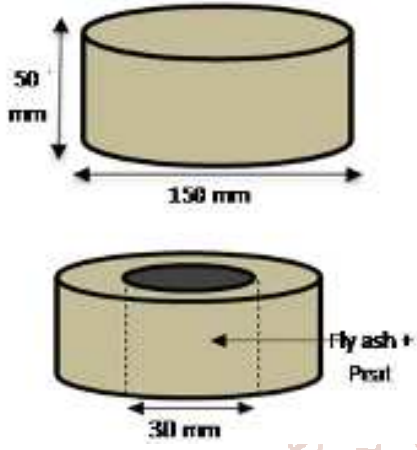

Figure 1 (a) - Raw peat sample (b) - Stabilized peat sample

\section{$2.2 \quad$ Numerical analysis}

Laboratory consolidation test using Rowe cell apparatus results were used to numerically stimulate the consolidation behaviour of peat and FA stabilized peat using Plaxis 2D numerical software.

An axisymmetric model was created with $75 \mathrm{~mm}$ width and $50 \mathrm{~mm}$ height. Selected material models were defined and one - way vertical drainage was allowed. For the material model, Soft - Soil - Creep (SSC) model was selected for peat as it is a soft soil with high degree of compressibility and Mohr - Coulomb model was selected to peat - FA stabilized column. The model parameters used for the analysis were adapted either from the experiment results or relevant literature and the values used for raw peat are shown in Table 2.

Table 2 - Parameters used for the numerical model

\begin{tabular}{|c|c|}
\hline Parameters & Values \\
\hline Unit weight $(\Upsilon)$ & $10.61 \mathrm{kN} / \mathrm{m}^{3}$ \\
\hline Initial void ratio $\left(\mathrm{e}_{\mathrm{o}}\right)$ & 2.03 \\
\hline Compression index $\left(\mathrm{C}_{\mathrm{c}}\right)$ & 0.67 \\
\hline Cohesion $(\mathrm{c})$ & $4 \mathrm{kPa}$ \\
\hline Friction angle $(\Phi)$ & $24.2^{\mathrm{o}}$ \\
\hline Dilatancy angle $(\psi)$ & $0^{\circ}$ \\
\hline
\end{tabular}

Distributed loads of 50, 100 and $200 \mathrm{kPa}$ were applied. Consolidation and stage construction (one - time loading) were used for the calculations. For the 10\% FA stabilized peat, interface element was defined along the intersection of the two samples to account ti.e difference of the friction between the samples and the factor input is 0.65 because the combined sample was rigid than the raw peat sample. The developed model geometry for raw peat and 10\% FA stabilized peat are shown in Figure 3.

To insert the central FA stabilized column [Figure 1(b)], a metal tube (30 $\mathrm{mm}$ diameter) was inserted centrally to the raw peat sample and the central peat core was extracted from the sample tube. The extracted peat core at its natural moisture was thoroughly mixed with $10 \%$ FA. The peat - FA mix was then placed into the metal core and the sample was compacted with 10 blows using a $2 \mathrm{~kg}$ rod [1]. The metal tube was finally withdrawn and the composite peat - FA central core was placed back into the hollow space of sample tube to form the composite sample [Figure 1(b)].The column formed in peat was of diameter $30 \mathrm{~mm}$ with a column - area ratio of $4.0 \%$. The samples were then cured for 7 days in a soaking basin before initiating the consolidation test using Rowe cell apparatus. Rowe cell apparatus used for the test is shown in Figure 2. Samples were consolidated under normal pressures of 50,100 and $200 \mathrm{kPa}$.

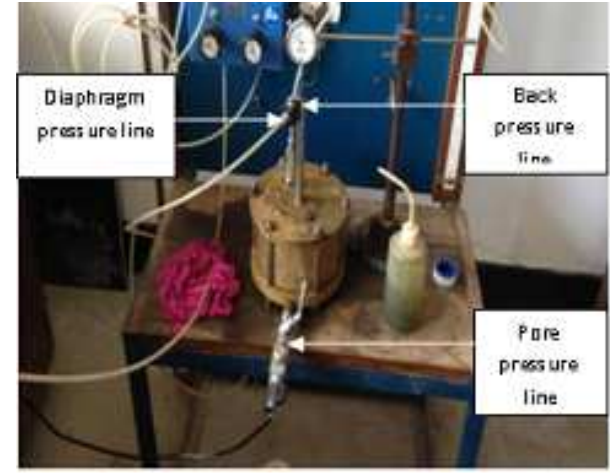

Figure 2 - Rowe cell apparatus used for the test

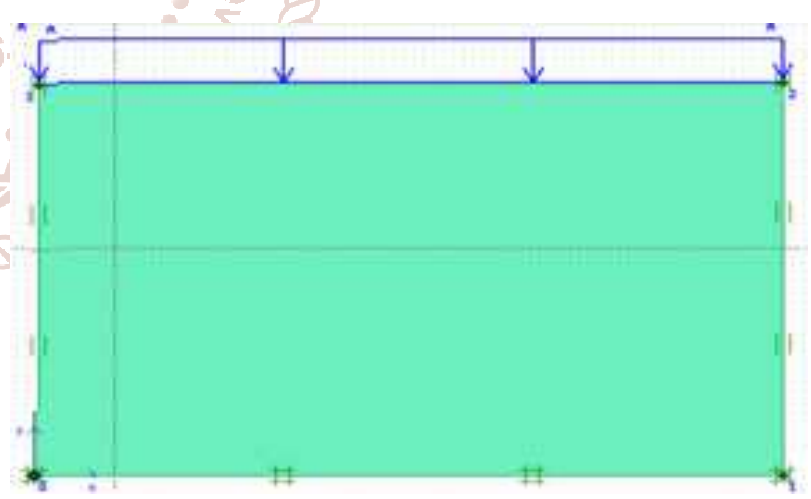

(a)

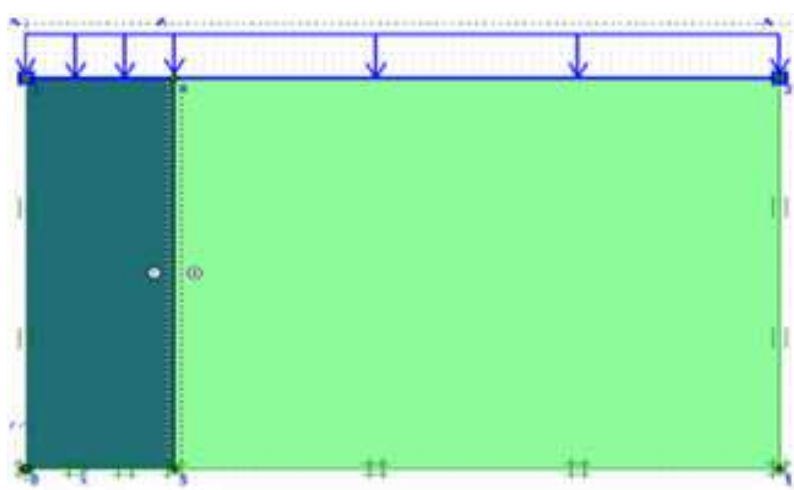

(b)

Figure 3 - Model geometry for (a) raw peat and (b) peat FA stabilized sample 


\section{Results and Discussion}

\subsection{Index properties test results}

Based on Von Post [14] classification [H $\mathrm{H}_{1}$ (completely fibrous) $-\mathrm{H}_{10}$ (completely amorphous)], peat falls into the $\mathrm{H}_{8}$ category. Therefore, this peat is classified as sapric amorphous peat. Index properties obtained for the raw peat are listed in Table 3.

Table 3 - Index properties test results

\begin{tabular}{|c|c|}
\hline Properties & Values \\
\hline Initial void ratio & 2.03 \\
\hline Bulk density/ $\left(\mathrm{kg} / \mathrm{m}^{3}\right)$ & 1081.7 \\
\hline Moisture content/ $(\%)$ & 192.1 \\
\hline Specific gravity & 1.63 \\
\hline Liquid limit/ $\%)$ & 176.5 \\
\hline Plastic limit & Non-Plastic \\
\hline Organic content/ $(\%)$ & 62 \\
\hline $\mathrm{pH}$ & 4.72 \\
\hline
\end{tabular}

\subsection{Direct shear test results}

Variation of shear stress vs shear displacement for raw peat is shown in Figure 4. Peak stresses were obtained for raw peat and FA stabilized peat and then values were plotted against the normal stresses $(50,100$ and $200 \mathrm{kPa})$. Variation of shear stress vs normal stress for peat and FA - peat samples are shown in Figure 5.

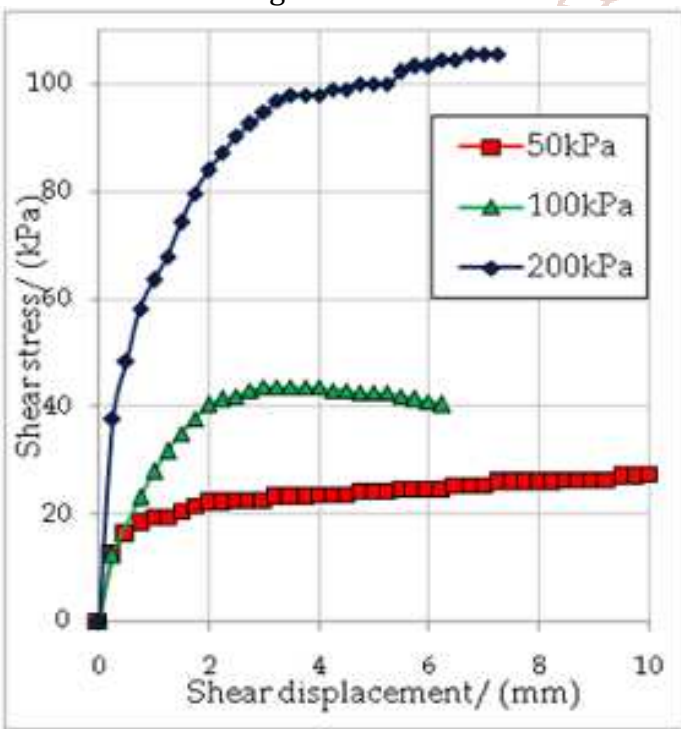

Figure 4 - Variation of shear stress vs shear displacement of raw peat

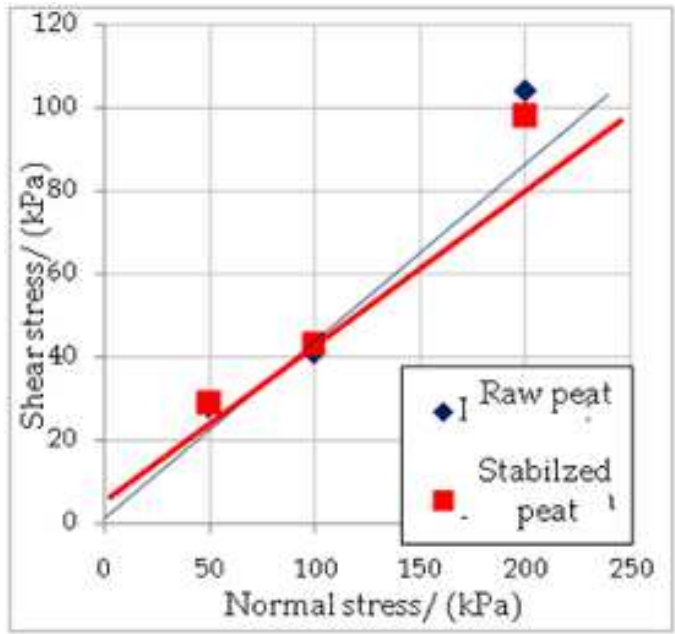

Figure 5 - Variation of shear stress vs normal stress for raw peat and stabilized peat
From Figure 5, cohesion (c) for raw peat and stabilized peat were found as 4 and $7 \mathrm{kPa}$ respectively, while friction angle $(\Phi)$ for raw peat and stabilized peat were $24.2^{\circ}$ and $21.8^{\circ}$ respectively. This is because the chemical reactions (hydration and pozzolanic reactions) between peat and FA produces long chain of stabilized peat molecules and it decreases initial void ratio, pre - consolidation pressure and physical properties. Therefore, peat molecules are packed well with the addition of FA which in turns increase $c$ and reduces $\Phi$ value of the stabilized peat $[3,8]$.

\subsection{Rowe cell test results}

Compressibility characteristics of raw peat and stabilized peat were studied using Rowe cell under normal pressures of 50, 100 and $200 \mathrm{kPa}$. Variation of settlement vs logarithmic time scale for raw peat and stabilized peat for loading conditions of 50,100 and $200 \mathrm{kPa}$ are shown in Figures 6 and 7 respectively. From Figures 6 and 7, it can be observed that settlement increases along with increase of normal stress which means void ratio decreases along with the increase of normal stresses.

The secondary compression index $\left(\mathrm{C}_{\alpha}\right)$ was found from settlement vs logarithmic time scale as shown in Figures 6 and 7. The $\mathrm{C}_{\alpha}$ value was found using Eq (1).

$$
\text { hthff } \mathrm{C}_{\alpha}=\left(\mathrm{e}_{2}-\mathrm{e}_{1}\right) / \log \left(\mathrm{t}_{2} / \mathrm{t}_{1}\right)
$$

where $e_{1}$ and $e_{2}$ are void ratios and $t_{1}$ and $t_{2}$ are time.

Coefficient of consolidation $\left(\mathrm{C}_{\mathrm{v}}\right)$ of the samples was obtained using Casagrande and Taylor's methods. In Casagrande method, the time taken for $50 \%$ consolidation $\left(t_{50}\right)$ for raw peat and

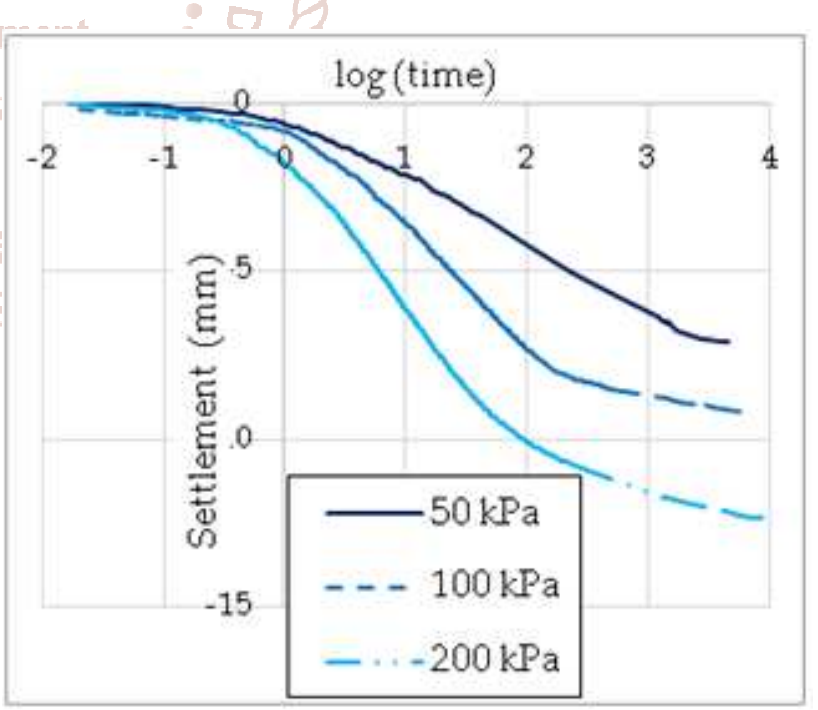

Figure 6 - Variation of settlement with logarithmic time of raw peat

stabilized peat were found from Figures 6 and 7 and then $C_{V}$ values were found using Eq (2).

$$
C_{v}=0.196 \times \mathrm{H}_{\mathrm{d}}^{2} / \mathrm{t}_{50}
$$

where $\mathrm{H}_{\mathrm{d}}$ is the drainage height of the sample and $\mathrm{t}_{50}$ is time required to archive $50 \%$ of consolidation. 
International Journal of Trend in Scientific Research and Development (IJTSRD) @ www.ijtsrd.com eISSN: 2456-6470

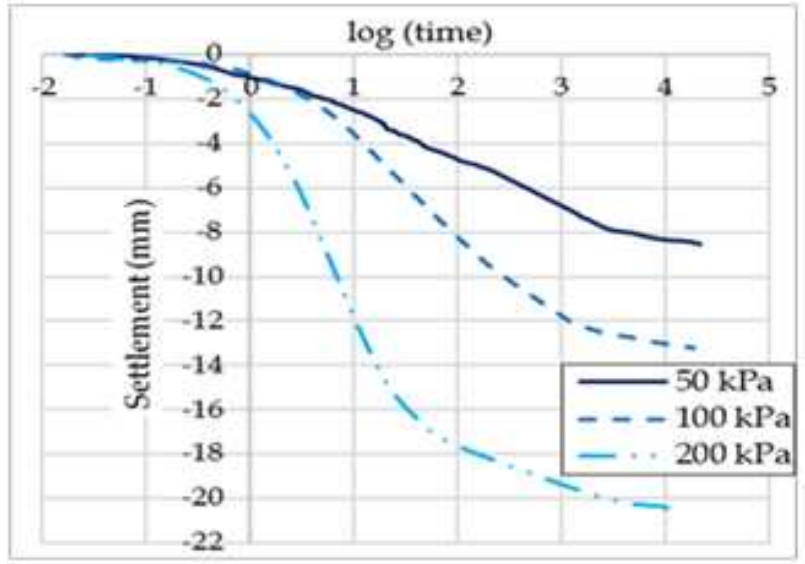

Figure 7 - Variation of settlement with logarithmic time of stabilized peat

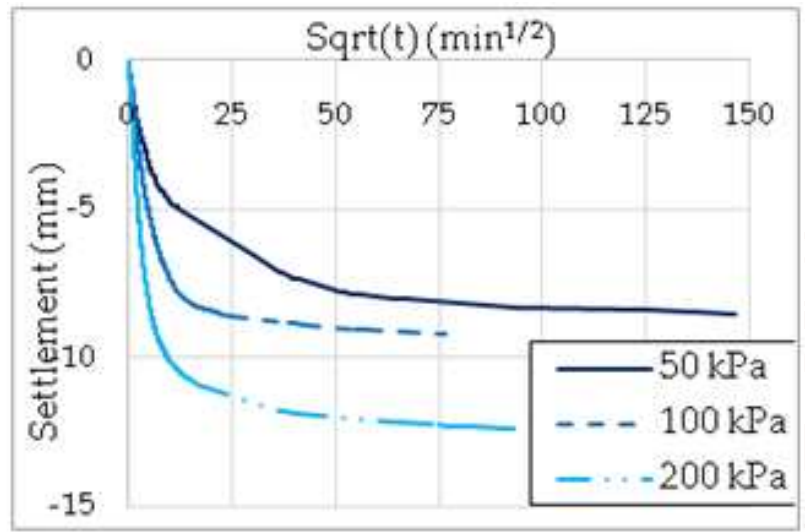

Figure 8 - Variation of settlement with square root time of raw peat

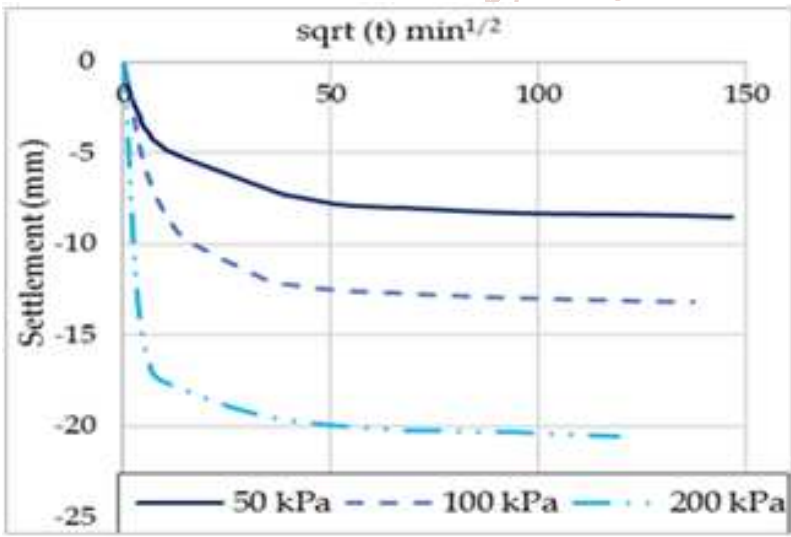

Figure 9 - Variation of settlement with square root time of stabilized peat.

In addition, another set of $\mathrm{C}_{\mathrm{v}}$ values were found using Taylor's method. Time taken for $90 \%$ consolidation $\left(\mathrm{t}_{90}\right)$ was found for raw peat and stabilized peat from Figures 8 and 9 respectively and $\mathrm{C}_{\mathrm{v}}$ values were found using Eq (3).

$$
\mathrm{C}_{\mathrm{v}}=0.848 \times \mathrm{H}_{\mathrm{d}}^{2} / \mathrm{t}_{90}
$$

where $\mathrm{H}_{\mathrm{d}}$ is the drainage height of the sample.
Average of the $C_{v}$ values obtained from Casagrande and Taylor's method was taken as $\mathrm{C}_{\mathrm{v}}$ of that sample. Using the average $C_{V}$ value, coefficient of permeability $(\mathrm{k})$ was calculated using Eq (4).

$$
\mathrm{k}=\mathrm{C}_{\mathrm{v}} \times \mathrm{m}_{\mathrm{v}} \times \Upsilon_{\mathrm{w}}
$$

where $m_{v}$ is the coefficient of volume compressibility and $\Upsilon_{w}$ is the unit weight.

The compressibility parameters obtained for raw peat and FA stabilized peat are shown in Table 4.

It can be clearly seen from Table 4that both $\mathrm{C}_{\mathrm{v}}$ and $\mathrm{C}_{\alpha}$ increases with normal pressure for both raw and stabilized peat whereas k decreases with increase in normal stresses. Compared to raw peat, all the compressibility parameters $\left(\mathrm{C}_{\mathrm{v}}, \mathrm{C}_{\alpha}\right.$ and $\left.\mathrm{k}\right)$ decreases with the addition of FA (Figures 10 and 11). This is because of the hardened peat - FA matrix formed due to hydration reaction, pozzolanic reaction and cation exchange that take place when FA comes into contact with water [8]. Depending on the normal stress, percentage reduction in $\mathrm{C}_{\mathrm{v}}$ and $\mathrm{C}_{\alpha}$ are $12.7 \%-33.4 \%$ and $7.1 \%-25.93 \%$ respectively.

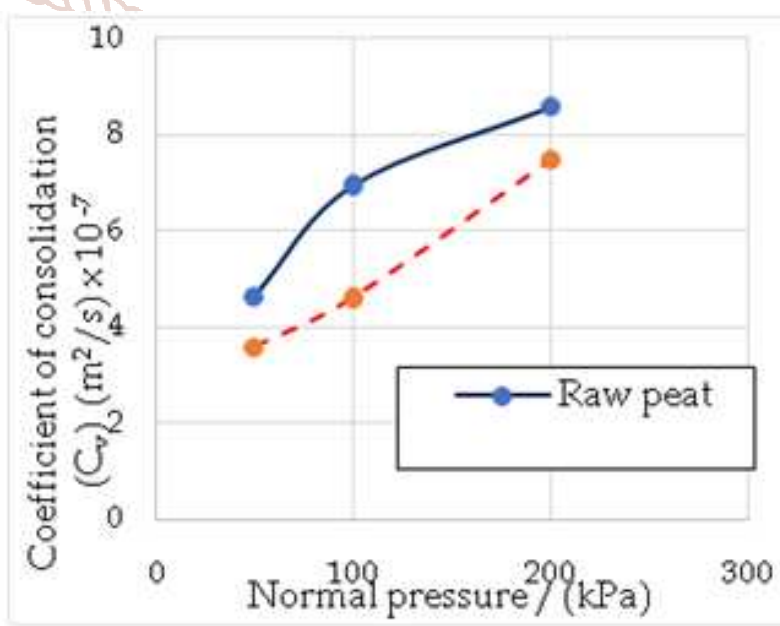

Figure 10 - Variation of coefficient of consolidation $\left(C_{v}\right)$ with normal pressure

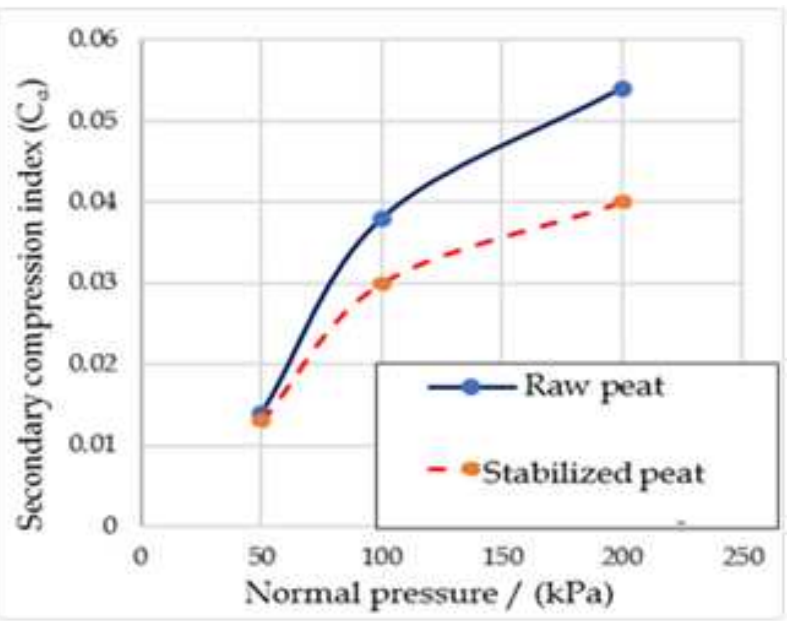

Figure 11 - Variation of secondary compression index $\left(\mathrm{C}_{\alpha}\right)$ with normal pressure 
International Journal of Trend in Scientific Research and Development (IJTSRD) @ www.ijtsrd.com eISSN: 2456-6470

Table 4 - Variation of consolidation parameters

\begin{tabular}{|c|c|c|c|c|}
\hline Sample & $\begin{array}{l}\text { Normal } \\
\text { stress }(\mathrm{kPa})\end{array}$ & $\begin{array}{l}\text { Secondary } \\
\text { compression index }\left(\mathrm{C}_{\alpha}\right)\end{array}$ & $\begin{array}{l}\text { Coefficient of consolidation } \\
\left(\mathrm{C}_{\mathrm{v}}\right) /\left(\mathrm{m}^{2} / \mathrm{s}\right)\left(\mathrm{x} 10^{-7}\right)\end{array}$ & 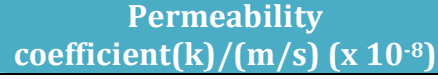 \\
\hline \multirow{3}{*}{$\begin{array}{l}\text { Raw } \\
\text { peat }\end{array}$} & 50 & 0.014 & 4.667 & 1.299 \\
\hline & 100 & 0.038 & 6.954 & 1.258 \\
\hline & 200 & 0.054 & 8.569 & 1.042 \\
\hline \multirow{3}{*}{$\begin{array}{c}\text { Stabilized } \\
\text { peat }\end{array}$} & 50 & 0.013 & 3.599 & 1.204 \\
\hline & 100 & 0.030 & 4.631 & 1.202 \\
\hline & 200 & 0.040 & 7.484 & 1.198 \\
\hline
\end{tabular}

Variation of void ratio with logarithmic pressure for raw peat and stabilized peat are shown in Figures 12 and 13 respectively. Based on Figures 12 and 13, pre - consolidation pressure values for peat and stabilized peat were calculated and the values were $95.5 \mathrm{kPa}$ and $70.8 \mathrm{kPa}$ respectively. Compression index $\left(\mathrm{C}_{\mathrm{c}}\right)$ was calculated from Figures 12 and 13 using Eq (5).

$$
\mathrm{C}_{\mathrm{c}}=\left(\mathrm{e}_{2}-\mathrm{e}_{1}\right) / \log \left(\mathrm{p}_{2} / \mathrm{p}_{1}\right)
$$

where $\mathrm{e}_{1}$ and $\mathrm{e}_{2}$ are void ratios corresponding to pressures $\mathrm{p}_{1}$ and $\mathrm{p}_{2}$ respectively.

The $\mathrm{C}_{\mathrm{c}}$ for raw peat and stabilized peat are 0.67 and 0.60 respectively. It is observed that the value $C_{c}$ was decreased when $10 \%$ FA was used. This is because of the stiffer matrix was formed due to hydration reaction, pozzolanic reaction and cation exchange that took place when FA reacted with water $[8,13]$.

\subsection{Numerical analysis results}

Experimental and numerical comparison between settlement vs time for raw peat and stabilized peat under 50 , 100 and $200 \mathrm{kPa}$ normal pressures are shown in Figures 14 and 15 respectively.

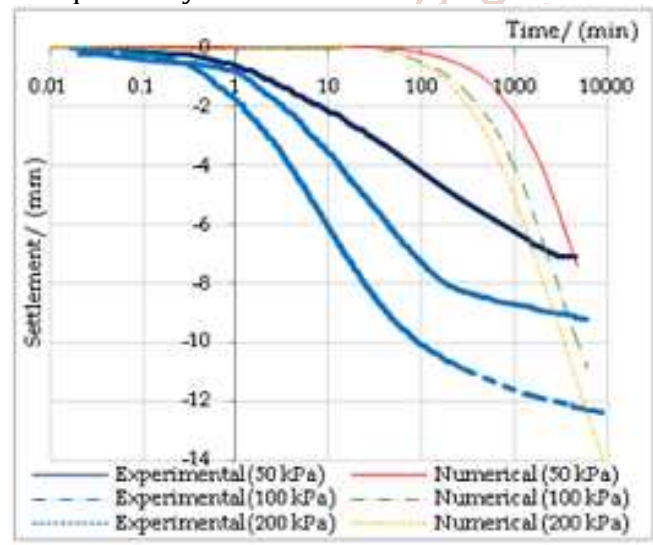

Figure 14 - Settlement - time curve of raw peat for 50 , 100 and $200 \mathrm{kPa}$ normal pressure

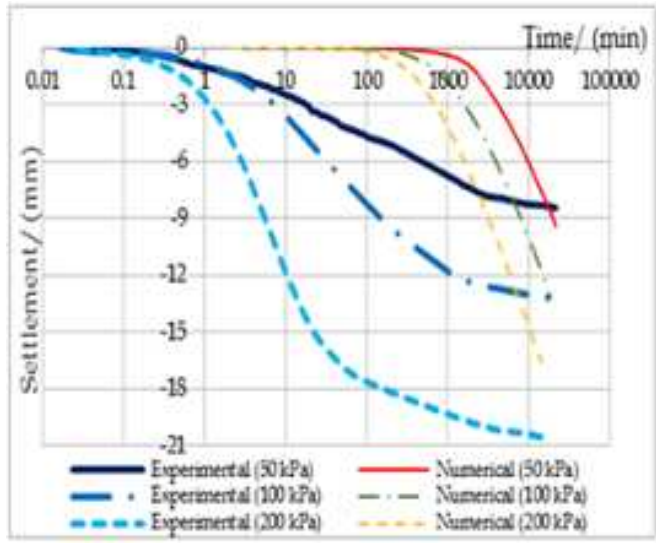

Figure 15 - Settlement - time curve of stabilized peat for 50,100 and $200 \mathrm{kPa}$ normal pressure
Based on Figures 14 and 15, it can be seen that there is a difference between the settlement - time plots obtained from experimental and numerical analysis at the beginning stage. This might be due to several reasons; (1) the assumptions made in numerical analysis that peat is highly heterogeneous material and the real behaviour could be vastly different compared to the assumed behavior (2) the primary/initial settlement found to be high in Rowe cell test that sample might be disturbed much when installing the FA core (3) The assumed interface element may be incorrect in order to incorporate the interaction between raw peat and stabilized peat (4) During the consolidation of peat, the void ratio is decreased; as a result the permeability of the soil is also reduced but this is not taken into account during the analysis due to lack of data in relation to variation of permeability with void ratio.(5) Since the model size is small, the boundary effects might not be minimized. But later stages there is a good agreement between the settlement time plots obtained from experimental and numerical analysis.

However, numerical analysis can predict the settlement time behaviour reasonably well at the end of consolidation. The deformed meshes for the raw peat and 10\% FA stabilized peat under $50 \mathrm{kPa}$ normal pressure are shown in Figures 16 and 17 respectively. Table 5 summarizes the settlement values obtained from experimental and numerical analysis at the end of consolidation period.

Based on Table 5, it can be seen that there is close agreement between experimental and numerical settlement values and hence Plaxis 2D can be used to model the consolidation behaviour of peat.

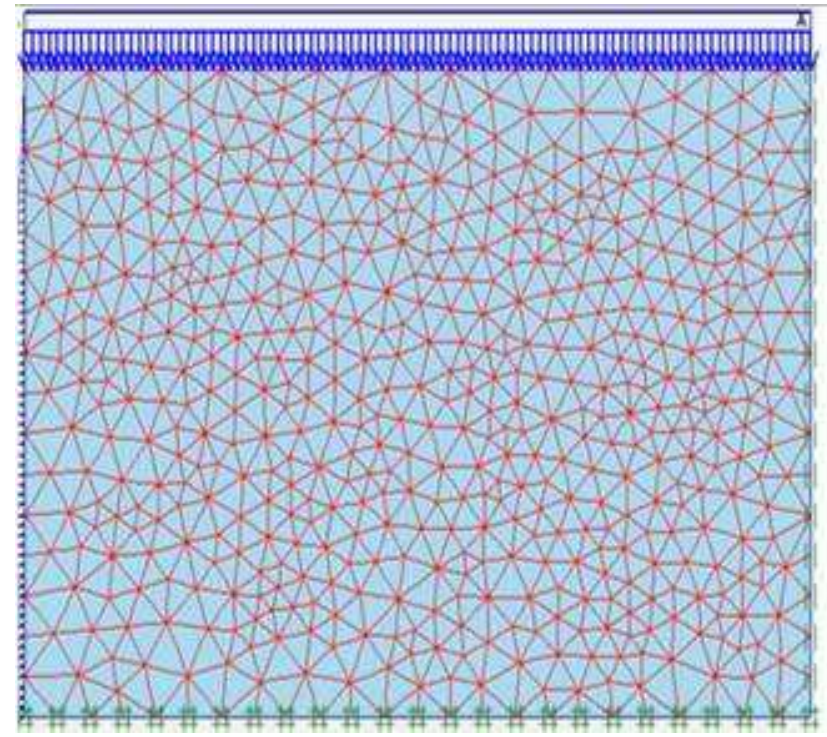

Figure 16 - Deformed mesh of raw peat for $50 \mathrm{kPa}$ normal pressure 


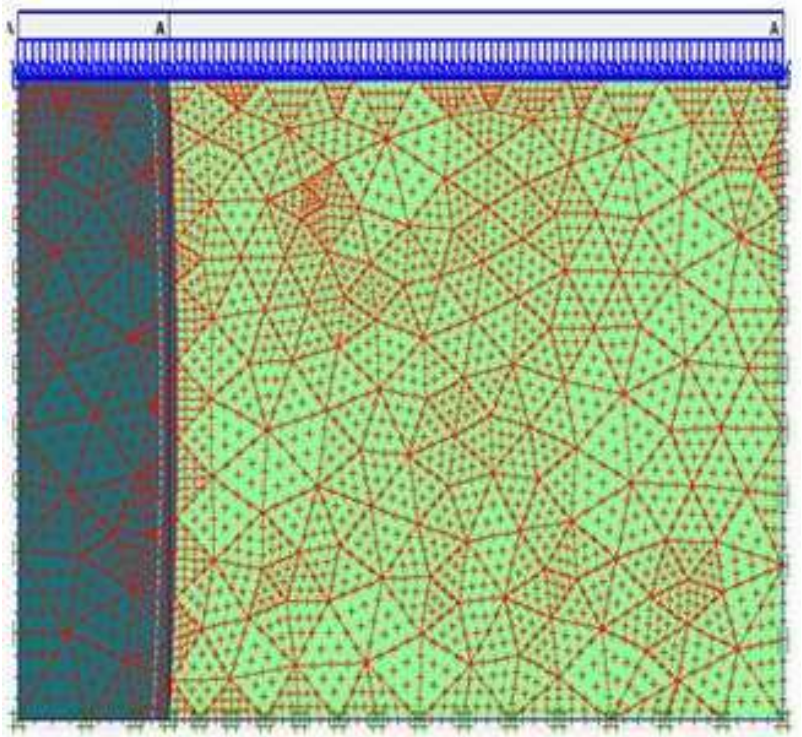

Figure 17 - Deformed mesh of stabilized peat for $50 \mathrm{kPa}$ normal pressure

Table 5- Variation of settlements

\begin{tabular}{|c|c|c|c|}
\hline \multirow{2}{*}{ Types } & $\begin{array}{c}\text { Normal } \\
\text { load } \\
(\mathrm{kPa})\end{array}$ & $\begin{array}{c}\text { Experimental } \\
\text { settlement } \\
(\mathrm{mm})\end{array}$ & $\begin{array}{c}\text { Numerical } \\
\text { settlement } \\
(\mathrm{mm})\end{array}$ \\
\hline \multirow{3}{*}{ Raw peat } & 50 & 7.1 & 7.4 \\
\cline { 2 - 4 } & 100 & 9.2 & 11.0 \\
\cline { 2 - 4 } & 200 & 12.4 & 13.8 \\
\hline \multirow{2}{*}{$\begin{array}{c}\text { Stabilized } \\
\text { peat }\end{array}$} & 50 & 8.5 & 9.4 \\
\cline { 2 - 4 } & 100 & 13.2 & 13.3 \\
\cline { 2 - 4 } & 200 & 20.5 & 16.6 \\
\hline
\end{tabular}

\section{Conclusions}

This study was carried out to investigate the compressibility behaviour of peat stabilized with FA using DMM. Based on the findings of this study, following conclusions can be drawn.

1. Von post classification test revealed that the peat used falls to the category of $\mathrm{H}_{8}$. Hence, this peat soil contains less fiber content, void ratio and known as sapric amorphous peat.

2. With the addition of FA, cohesion value of peat increases while friction angle value decreases and the reason for this is stabilized peat molecules are produced due to chemical reactions between peat and FA in the presence of moisture in peat and stabilized the peat.

3. Consolidation parameters such as compression index $\left(\mathrm{C}_{\mathrm{c}}\right)$, coefficient of secondary compression $\left(\mathrm{C}_{\alpha}\right)$ and coefficient of consolidation $\left(\mathrm{C}_{\mathrm{V}}\right)$ reduces with the addition of FA. This indicates that FA can be used to stabilize peat. Percentage reduction in $\mathrm{C}_{\mathrm{v}}, \mathrm{C}_{\alpha}$ and $\mathrm{C}_{\mathrm{c}}$ are $33.4 \%, 25.9 \%$ and $10.5 \%$ respectively.

4. Findings of numerical study suggest that consolidation behaviour of peat can be simulated using Plaxis 2D. There is a reasonably good agreement between the settlement value obtained from experimental and numerical works.

5. On the whole, compressibility parameters reduce significantly with the introduction of FA and this can lead to significant reduction in the settlement and improvement in bearing capacity when peat - FA deep mixing columns are used.

\section{References}

[1] Ambily A. P. and Gandhi S. R. (2007), "Behaviour of Stone Columns Based on Experimental and FEM Analysis", Journal of Geotechnical and Geo Environmental Engineering, Vol 133(4), 405-415.

[2] American society for Testing and Materials (2008), Book of ASTM Standards.

[3] Azhar A. T. S., Norhaliza W., Ismail B., Abdullah M. E. and Zakaria M. N. (2016), "Comparison of Shear Strength Properties for Undisturbed and Reconstituted ParitNipah Peat, Johor", International Engineering Research and Innovation Symposium.

[4] Banadaki A. D., Ahmad K. and Ali N. (2013), "Influence of natural fillers on shear strength of cement treated peat", Gradevinar, Vol 7, 633-640.

[5] Bord and Mona (1984), "Fuel peat in developing countries", Study report for World Bank, Dublin.

[6] Duraisamy Y., Huat B. B. K. and Aziz A. A. (2007), "Engineering properties and compressibility behaviour of tropical peat soil", American J. of Engineering and Applied Sciences 4, Vol 10, 768-773.

[7] Duraisamy Y., Huat B. B. K. and Aziz A. A. (2007), "Methods of utilizing tropical peat land for housing scheme", American Journal of Environmental Sciences 3, Vol 4, 259-264.

[8] Huat B. B. K., Kazemian S., Prasad A. and Barghchi M. (2011), "A study of the compressibility behaviour of peat stabilized by DMM: Lab model and FE analysis", Scientific Research and Essays, Vol. 6(1), 196-204.

[9] Huat B. B. K., Kazemian S., Prasad A., Bazaz J. B., Aziz F. N. A. A., Mohamed T. A. (2010), "Influence of cementsodium silicate grout admixed with calcium chloride and kaolinite on sapric peat", Journal of civil engineering and management, Vol 17, 309-318.

[10] Huat B. B. K., Maali S. and Mohamed T. A. (2005), "Effect of chemical admixtures on the engineering properties of tropical peat soils", American J. of Engineering and Applied Sciences 2, Vol 7, 1113-112.

[11] Kolay P. K., Sii H. Y. and Taib S. N. L. (2011), “Tropical peat soil stabilization using class $\mathrm{F}$ pond ash from coal fired power plant", International Journal of Civil Engineering 3, Vol 2.

[12] Moore P. D. (1989), "The ecology of peat forming processes", Int. J. Coal Geol, Vol 12, 89-103.

[13] Phanikumar B. R. (2009), 'Effect of lime and fly ash on swell, consolidation and shear strength characteristics of expansive soils: a comparative study', Geomechanics and Geoengineering, Vol $4(2), 175-181$.

[14] Von Post L. (1922), "SGU peat inventory and some preliminary results", Vol 1, 1-27. 